\title{
The Impact of Basel III on the Operations of Retail Banks
}

\author{
Eric Lamarque
}

Professor at the Sorbonne Graduate Business School - University of Paris 1 Panthéon Sorbonne

\section{GREGOR - Chair Management and Governance of financial Cooperatives}

For many bankers, Basel III has led to a change of epoch, a change of model and for some even a change of profession. These views initially reflect the content of the Basel principles relating to two major indicators of bank stability, namely: i) solvency via the level of equity capital required, and ii) liquidity in terms of assets held. The mainstream financial press and bankers have largely discussed the impact of these measures on banking sector and the wider economy. There is no doubt that they have significant consequences on banks' activities and financing capacity. But Basel III also deals with other issues relating to the organisation and governance of financial institutions. These have been less publicised, but affect banks and the way actors operate on a daily basis as much, if not more.

Basel III is a system based on three pillars. Pillar 1 is detailed throughout EU Directive CRD4. It concerns the definition of equity required to cover exposure to credit, market and operational risks. Such exposure is gauged by risk weighted assets (RWAs), and regulatory equity capital is defined differently compared to usual accounting definitions. Pillar 2 leads to the implementation of control measures of equity capital, of exposure to risks. It also includes measures to be pursued to meet these requirements. Lastly, Pillar 3 relates to market discipline, with emphasis on the information financial institutions must communicate in terms of risks.

The motives of regulators in adopting Basel III clearly follow the banking crisis in September 2008: they seek to ensure that governments will no longer be obliged to protect banks from filing bankruptcy. The decisions to take capital holdings in banks in October 2008 were not understood by the public, even if the public monies committed were recovered with a profit. The political cost of such interventions has been so high that it is no longer possible for governments to find themselves in a similar situation. Public regulators have had the mission of reinforcing the safety and financial stability of banks, as well as ensuring and reinforcing the quality of internal bank controls and those carried out by national and European supervisory agencies.

The European Capital Requirements Directive (CRD 4) runs to nearly 340 pages. It covers the three pillars and aims to provide precise recommendations on how banks can protect themselves against insolvency risks with sufficient levels of equity capital, and how to protect themselves against liquidity risks to prevent sudden bankruptcies. These two risks lie at the heart of regulatory concerns. But the Directive also addresses the conditions under which banks are supervised, the bodies involved in such supervision and the resolution mechanisms they put into place. Basel III therefore addresses criteria for risk and financial management as much as it stresses organisational and strategic criteria.

The aim of this chapter is to review and assess the two dimensions of the consequences induced by these new texts. It seeks to see what is truly new and how financial institutions will adapt - more or less easily - to the new conditions for exercising their trade. 
The chapter will therefore focus on two questions. It will look first at how Basel III envisages improving banks' solvency, mainly in their retail activities. The aim is to assess the improvement in institutions' financial stability. Subsequently, the chapter will review the principles put forward to improve banks' control by focussing on the organisation of internal control, the resolution mechanisms and the role played by governance bodies which have a special place in Basel III.

In these two areas, particular attention will be paid to how the new regulations affect cooperative banks, which are a particular type of actor in the retail banking. This sector is indeed characterised by a diversity of governance models. Financial cooperatives have a special position, especially in France, where they are even dominant actors. The regulations set out in Basel III make no distinction concerning such banks, assuming that operating conditions should be the same for everyone. Furthermore, the cooperative sector as a whole has to deal with special legislation that sometimes interferes with measures put forward by regulators. This chapter also sets out to address these specific issues.

\section{Improving the Reliability and Safety of Financial Institutions}

The question of improving banks' safety is the very basis of the Basel Committee's existence, which has looked at the matter for nearly 30 years. The risk to solvency may be defined as the risk of a bank not being able to meet losses linked to its activities (credit, markets and operations). In this case, equity capital must be able to cover losses. As with any company, liquidity risks involve not being able to meet short term payments. The two are linked, but the Basel Committee has only been interested in the latter since the 2008 banking crisis. This chapter starts by examining issues linked to equity capital and the consequences for banks, as well as their clients. It then examines problems of liquidity, in order to identify changes to the financial management of banks.

\subsection{The progressive increase in capital equity required by regulators}

Basel I introduced the requirement for banks to cover their credit risks with sufficient equity, at the end of the 1980s. Equity capital had to be equivalent to $8 \%$ of risk exposure. The Basel II agreement, which were initiated in 2004, came into force in January 2007. They extended the range of risks covered, by including market risks and operational risks, while maintaining the $8 \%$ threshold. However, the impact of this agreement was not really felt, due to the rapid increase in bank failures that year. Basel III was signed in 2010, and will be fully implemented by 2019. It has not changed the risks requiring cover, but it has raised equity capital requirements further, bringing these up to a minimum of $10.5 \%$ and even $15 \%$ in certain cases. Basel III has also brought in new demands in terms of liquidity: the table below sets out the accord's obligations.

\begin{tabular}{|l|l|}
\hline & \multicolumn{1}{c|}{ From Basel II to Basel III } \\
\hline $\begin{array}{l}\text { Pillar 1 } \\
\text { Equity capital } \\
\text { requirements }\end{array}$ & $\begin{array}{l}\text { The minimum requirements in equity capital in view of the assessment of exposure to } \\
\text { credit, market and operational risks }\end{array}$ \\
Prudential equity capital
\end{tabular}




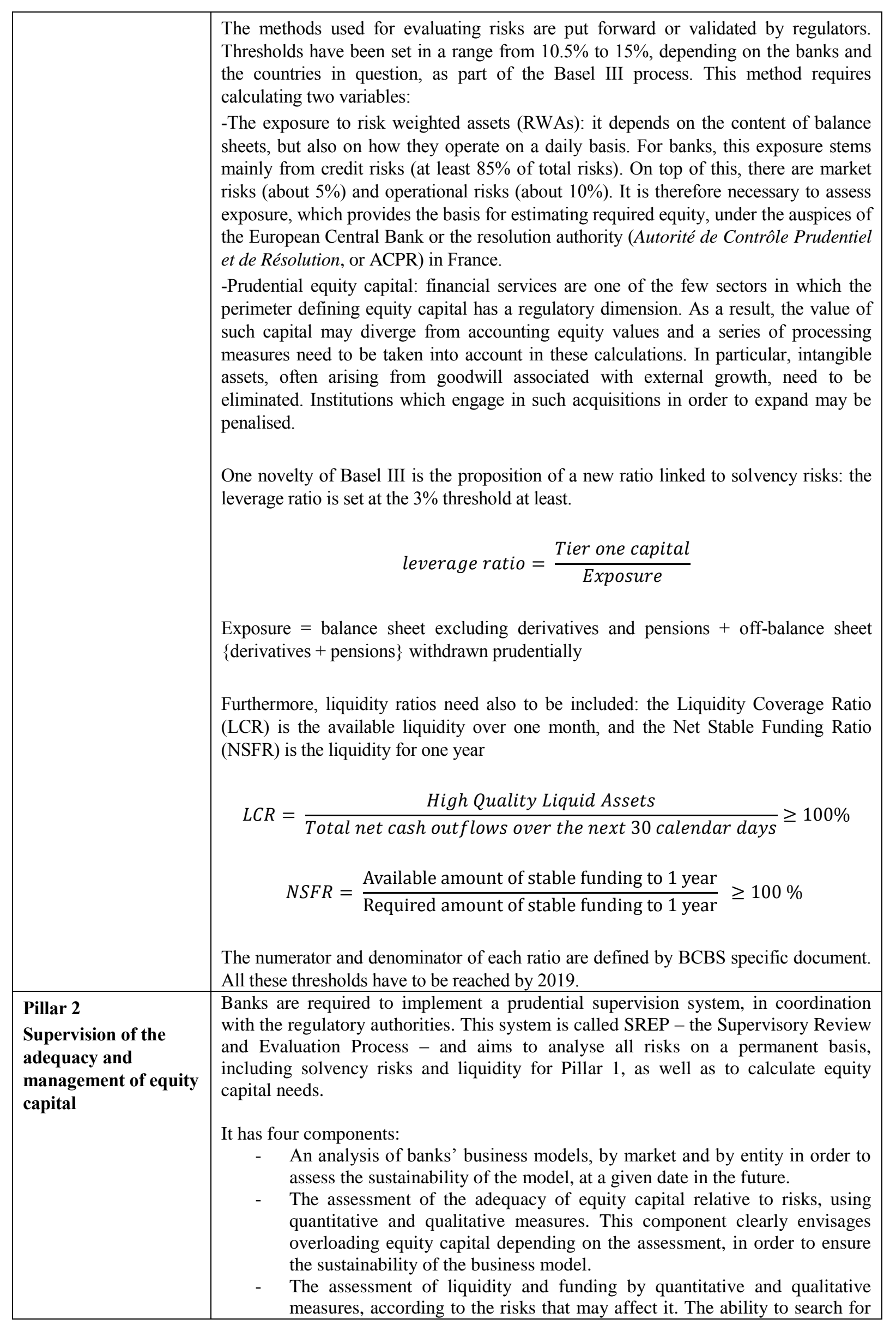




\begin{tabular}{|l|l|}
\hline & $\begin{array}{c}\text { resources is a key aspect of this assessment. } \\
\text { The assessment of governance, as well as management and control } \\
\text { processes. This component complements the implementation of the internal } \\
\text { control system which has existed for several years in France, in particular. }\end{array}$ \\
& $\begin{array}{l}\text { The supervisor can demand higher equity capital or the implementation of any action } \\
\text { capable of improving the safety of the institution. }\end{array}$ \\
\hline $\begin{array}{l}\text { Pillar } 3 \\
\text { Market discipline }\end{array}$ & $\begin{array}{l}\text { This pillar aims at improving banks' financial transparency, obliging them to } \\
\text { communicate information needed to allow third parties to appreciate the adequacy of } \\
\text { their equity capital. It is hoped that this will lead to better market discipline. }\end{array}$ \\
\hline
\end{tabular}

Source: adapted from the BIS - Basel Committee, European Commission and ECB.

The general principle is that prudential equity capital is equal to a minimum of banks' exposure to risks, according to the principles of banking regulation. In the case of the Basel III framework, all actors expect that equity requirements will rise, even if thresholds are not increased, given present portfolio activities and assets held on balance sheets. If on top of this, requirements continue to rise, as is the case for banks, then considerable changes have been envisaged by banks, in terms of strategic and commercial positioning, including withdrawing or reducing finance to certain types of clients. Three trends can be identified today, as follows.

\subsubsection{The reduction in the risk exposure}

Banks track permanently the use of equity capital associated with each of their activities and especially their credit policy. As shown in Example 1 below, the latter influence the amount of required equity capital, first and foremost.

The table indicates that two factors affect total exposure in particular: credit risk accounts for more than $71 \%$ of total exposure. This does not include counterparty risks, the importance of exposure to risks associated with international activities, in respect to the scale of such activities in banks' balance sheets.

\section{i- $\quad$ The consequences in terms of credit risk policies}

The mechanics of calculating required equity capital under Basel II was relatively simple. The more a bank finances a risky client, the more equity it has to accumulate to deal with bankruptcy. The more a bank is exposed to a sector which is sensitive to economic conditions, the more it has to cover itself. A bank's policy in terms of taking risks determines its capital requirements directly. This situation is especially sensitive in the corporate market (especially for small and medium-sized enterprises). This market has traditionally been more risky than the household sector.

Example 1: The Exposure to Risks Measured by RWAs 


\begin{tabular}{|c|c|c|c|c|c|c|c|}
\hline \multirow[b]{3}{*}{$\begin{array}{l}\text { RWAS } \\
\text { Inmmillonsofeuros }\end{array}$} & \multicolumn{7}{|c|}{ 31December 2015} \\
\hline & \multicolumn{2}{|c|}{ Retail Banking\& Services } & \multicolumn{3}{|c|}{ Corporate\& Institutional Banking } & \multirow[b]{2}{*}{$\begin{array}{r}\text { Other } \\
\text { activities }\end{array}$} & \multirow[b]{2}{*}{ Total } \\
\hline & $\begin{array}{c}\text { Domestic } \\
\text { Markets }\end{array}$ & $\begin{array}{r}\text { Intemational } \\
\text { Financial } \\
\text { Services }\end{array}$ & $\begin{array}{l}\text { Corporate } \\
\text { Banking }\end{array}$ & $\begin{array}{r}\text { Global } \\
\text { Markets }\end{array}$ & $\begin{array}{r}\text { Securities } \\
\text { Services }\end{array}$ & & \\
\hline Credit risk & 179,089 & 141,022 & 92,042 & 8,988 & 1,440 & 26,700 & 449,282 \\
\hline IRB approach & 116,985 & 14,377 & 86,769 & 6,396 & 1,069 & 3,145 & 228,740 \\
\hline Standardised approach & 62,105 & 126,645 & 5,273 & 2,592 & 372 & 23,556 & 220,542 \\
\hline $\begin{array}{l}\text { Banking book } \\
\text { securitisation }\end{array}$ & 909 & 646 & 221 & 9,676 & 1 & 1,173 & 12,625 \\
\hline IRB approach & 757 & 79 & 221 & 9,675 & 1 & 1,173 & 11,905 \\
\hline Standardised approach & 151 & 567 & 0 & 2 & 0 & 0 & 720 \\
\hline Counterparty credit risk & 2,636 & 909 & 23 & 24,021 & 1,548 & 91 & 29,228 \\
\hline $\mathrm{CCP}$ & 0 & 0 & 0 & 1,385 & 1,048 & 0 & 2,432 \\
\hline CVA charge & 138 & 334 & 22 & 2,919 & 12 & 81 & 3,507 \\
\hline $\begin{array}{l}\text { Counterparty credit risk - } \\
\text { excL. CCP and CVA charges }\end{array}$ & 2,498 & 575 & 1 & 19,718 & 488 & 10 & 23,289 \\
\hline Equity risk & 5,329 & 33,595 & 2,869 & 1,962 & 358 & 13,966 & 58,079 \\
\hline Market risk & 170 & 424 & 1,488 & 19,573 & 57 & 2,052 & 23,764 \\
\hline Internal model & 0 & 28 & 280 & 18,693 & 0 & 2,038 & 21,039 \\
\hline Standardised approach & 170 & 395 & 1,208 & 142 & 57 & 14 & 1,986 \\
\hline $\begin{array}{l}\text { Trading book securitisation } \\
\text { positions }\end{array}$ & 0 & 0 & 0 & 739 & 0 & 0 & 739 \\
\hline Operational risk & 16,367 & 15,706 & 9,122 & 15,456 & 2,675 & 1,222 & 60,548 \\
\hline TOTAL & 204,501 & 192,301 & 105,765 & 79,677 & 6,079 & 45,203 & 633,527 \\
\hline
\end{tabular}

Source: Document de Référence, BNPP, 2015.

Some sectors are impacted by economic conditions and the business cycle. They risk facing credit rationing, because default risks are too high. The principle of individualised credit rating for each "corporate" client is now a key instrument in decision making.

Looking at the above example in detail, it is clear how trends in the exposure to risks are combined with an increase in thresholds under Basel III.

Example 2: Trends in RWA Credit and Equity Capital Requirements

\begin{tabular}{|l|c|c|c|c|c|c|}
\hline$€$ billions & $\begin{array}{c}\mathbf{2 0 1 5} \\
\text { Basel } \\
\text { III }\end{array}$ & $\begin{array}{c}\mathbf{2 0 1 4} \\
\text { Basel } \\
\text { III }\end{array}$ & $\begin{array}{c}\mathbf{2 0 1 3} \\
\text { Basel III }\end{array}$ & $\begin{array}{c}\mathbf{2 0 1 3} \\
\text { Basel II } \\
\mathbf{1} / \mathbf{2}\end{array}$ & $\begin{array}{c}\mathbf{2 0 1 2} \\
\text { Basel II } \\
\mathbf{1} / \mathbf{2}\end{array}$ & $\begin{array}{c}\mathbf{2 0 1 1} \\
\text { Basel II }\end{array}$ \\
\hline Total credit granted & 685 & 657 & 612 & 617 & 630 & 666 \\
\hline Total RWA credit & 449 & 442 & 418 & 411 & 411 & 446 \\
\hline Equity capital required to cover credit risk & 35.9 & 35.3 & 33.4 & 32.8 & 33 & 35.7 \\
\hline RWA "company" credit & 257 & 246 & 232 & 234 & 236 & 254 \\
\hline $\begin{array}{l}\text { Equity capital required to cover "company" } \\
\text { credit risks }\end{array}$ & 20.6 & 19.6 & 18.5 & 18.7 & 18.8 & 20.3 \\
\hline
\end{tabular}

Source: Documents de Référence, BNPP

It is clear here that the reduction in exposure to credit risk between 2011 and 2012 allowed the bank to "save" €2.7 billion in equity capital. Conversely between 2013 and 2014, the rise in exposure meant that another $€ 2$ billion had to be found. Lastly, between 2014 and 2015, the volume of credit distributed expanded by $4 \%$, but total exposure only increased by $1.6 \%$. This implies that such credit was mainly granted to safe counterparties. 
In addition, companies represent more than half of this total exposure, and hence the variations of exposure on this market affect regulatory capital first and foremost.

For all retail banks, three factors explain the changes in exposure:

- The quality of borrowers: the more banks lend to highly ranked borrowers ( 1 to 2 on a scale running to 9) the more RWAs will be minimal or even zero. Thus the best clients will have no problems in satisfying their demand for credit, whereas the most risky borrowers will have problems in obtaining finance. This is especially so for SMEs.

- The economic situation: in times of slow or even negative growth, the number of troubled borrowers will increase. When specific sectors are facing problems, risks to actors increase. At that point, exposure and equity capital increase for a given level of debt. As a result, certain sectors experiencing worsening economic problems risk having less access to bank finance.

- The volumes of credit granted: the volume of credit granted impacts the level of RWAs upwards or downwards, in a fairly mechanical way. In economic slowdowns, retail clients borrow less and vice-versa.

It is hard to say which of these three effects has been the most important in recent years. All have been significant undoubtedly. But, economic actors with average rating clearly face real difficulties, or at least are at the limit of what banks accept today. Institutions quite evidently set themselves boundaries which are not overstepped. Credit policy thus includes a new dimension which is more or less explicit, namely clients' ratings.

In the retail banking sector, this conflicts with the positioning sought by cooperative banks in terms of risk policy, and raises questions of the ability of actors to pursue more accommodative policies in this area. Indeed, within the framework of their local (territorial) commitment to local firms, some cooperative players are more inclined to accept and finance clients with more risky ratings. Such a policy is consistent with their cooperative engagements. But it generates problems because this policy automatically leads to greater equity requirements. Cooperative banks cannot therefore increase their shares of such clients without having large surpluses of equity capital and accepting the costs of higher risks.

This illustrates a phenomenon which we will find throughout this chapter, namely the fact that regulatory principles largely oppose the natural positioning of cooperative banks. As a result, they too behave more and more like traditional banks, favouring less risky clients too. In fact, they often argue that their specificity lies in the fact that they carry lower risks, which is quite paradoxical.

ii- When retail banks develop internationally

External growth strategies are largely favoured by retail banks to obtain positions in new countries. These strategies may not always be successful. However, the search for new sources of growth and the acquisition of banks with many clients is always tempting. But such growth also generates extra credit risks and extra operational risks.

Credit risks arise because most of these acquisitions take place in emerging countries, where policies for granting loans are probably less supervised than in France. Risks in the company sector are more important and the quality of information they provide to assess default risks is not the same as in 
developed countries. Moreover, systems of evaluation are not exactly identical and so there are problems with reporting and consolidation of exposure to such risks. This can put a brake on such initiatives, given that the quality of data on risks is an important issue at present, due to reforms concerning the principles for registering accounts.

Lastly, the acquisition of retail banks in a foreign country often leads to an increase in operational risks that come under Basel III. These risks are linked to the inadequacy of the systems, procedures and practices, as well as to external events that may lead to direct losses, legal risks or more often to reputational risks. Credit activity is subjected to these kinds of risks when procedures are not respected and clients are granted loans they should not have been able to obtain. These risks also arise in the collection of deposits, when measures appropriate to controlling the origin of funds collected are not implemented.

The distance between the subsidiary and the parent company makes it more difficult to implement required controls. Automatically, this leads to higher risks and hence a greater demand for equity capital. International development thus requires more investment in equity.

Credit policies and international development are two fundamental components of investment banking. Since the beginning of 2015, Pillar 2 has come into force, and actors have to think in terms of risk appetite. As a result, there is an explicit link between strategic positioning in terms of products, clients and geographical zones, as well as the exposure to risks. A way for managing such exposure clearly resides in the redefinition of bank's business model, unless it has no problems in finding the equity capital required to cover risks. Here again, the diversity of models within the banking sector means that many actors have to be taken into account, especially financial cooperatives. Actors may not always be able to deal with positions they may take, concerning clients facing the greatest difficulties.

For universal banks, changes to their business model involve dropping certain activities in some countries. Several actors have sold some activities deemed to be non-strategic in recent years, though on the basis of criteria that are not very clear. Apart from the two cases referred to in the previous table, the sale by BBVA of its life-insurance subsidiary in Spain may be mentioned, as can the management of assets by Santander. In France, Société Générale has pulled out of the asset manager Amundi, while BNPP has given up insuring certain types of financing (planes and ships), and has reduced its investment banking activities in several geographic regions. Consumer credit and credit leasing have also been much affected by the rundown of operations.

Finding a new balance between strategic positioning and the capacity for satisfying equity capital requirements has become the decision-making model of the sector today.

\subsubsection{Raising equity capital and the capacity to absorb losses}

The preceding examples all point to the conclusion that equity capital needs to be increased. Table 3 shows the strong rise in capital for shareholder capital banks. Generally speaking, the equity capital of European banks rose by nearly 50\% between 2009 and 2014, and is expected to rise by a further $25 \%$ by 2018. 
Table 3: Change in Equity Capital with Respect to Balance Sheets (in € billions) ${ }^{1}$

\begin{tabular}{|l|c|c|c|c|}
\hline Banks & Book equity 2007 & $\begin{array}{c}\text { Total balance } \\
\text { sheet 2007 }\end{array}$ & Book equity 2015 & $\begin{array}{c}\text { Total balance } \\
\text { sheet 2015 }\end{array}$ \\
\hline Société Générale & 31 & 1071 & 62.6 & 1334 \\
\hline BNPP & 59 & 1694 & 100 & 1994 \\
\hline BPCE & $47.8(2009)$ & $1029(2009)$ & 57.6 & 1166 \\
\hline CA SA & 46 & 1414 & 59.4 & 1529 \\
\hline
\end{tabular}

Apart from what has been already highlighted out in the preceding point concerning the need to change banks' business model to raise the level of equity capital, regulatory changes also impose new management of equity in retail banks. There are three components to this:

i- $\quad$ Further improvement of financial results: the most virtuous way to achieve this increase is above all to raise operational performance and to have the capacity to improve net earnings. Looking at the situation of retail banks today, however, shows that achieving this goal is difficult, and banks are increasing layoffs across the world. The first reason for this lies in the fall in interest rate spreads (the difference between the rates paid by clients and the rates at which banks can refinance themselves). The fall in rates has led to a wave of loan renegotiations by clients. As banks favour less risky clients, interest rate margins have fallen all the more. This fall in interest rate spreads has not been compensated by higher commissions on the sale of products and services (as most clients do not easily accept such payments), nor by higher returns on market products. The latter have in fact been affected by new regulations concerning market risks, which push banks and other institutional investors to turn towards safer financial products (such as government bonds), that are less profitable.

Net bank earnings have therefore been stagnating in France for two years and forecasts are not optimistic. As a result, the only way to obtain margins is by limiting operational costs (more than $60 \%$ of which are made up of wage bills), and limiting the costs of risks (see Lamarque, 2014). This leads to credit policies that are as riskless as possible, which in turn weighs on GDP...

ii- $\quad$ Paying fewer dividends to shareholders: a seductive solution for many is to limit payments to shareholders and hence retain more earnings for equity capital. Publicly listed banks and more generally banks with shareholder capital however face a dilemma. Limiting dividends over the long term runs the risk of encouraging potential investors and existing shareholders to turn to other shareholdings. The most spectacular example in recent years has been the way General Electric (GE) has pulled out of financial services, which accounted for half the group's earnings in 2000. Not only have immediate returns on dividends been reduced, but falls in stock prices following the crisis in $\mathbf{2 0 0 8}$ have yet to be recovered, despite a general rise in market values.

\footnotetext{
${ }^{1}$ Consolidated accounts for BPCE have only been available since 2009.
} 
The main explanation for this is a structural decline in Return on Equity (ROE or financial profitability), which is a benchmark for many shareholders. Not only are earnings no longer rising, in fact they are stagnating and falls are to be expected. At the same time, equity capital requirements are rising endlessly. For retail banking, ROE has fallen from between $12 \%$ and $15 \%$ in 2007 , to between $6 \%$ and $8 \%$ today.

iii- Having the capacity to raise equity capital quickly: the last solution to raising equity capital is to have quick access to investors who can provide further capital. A publicly listed bank has an advantage from this point of view, because it is easy to issue new shares, even though this may lead to a low share price. To overcome uncertainties faced by shareholders, the regulator is now clearly envisaging the possibility of transforming bond debt into capital in an authoritarian way, which broadens the notion of equity capital. ${ }^{2}$

This raises a new problem faced by cooperative banks, as the retention as equity capital of all net earnings lies at the very heart of the cooperative system, which is not constrained by the fact of having to reward shareholders. Cooperative banks should have an advantage from this point of view. However, the regulator and supervisor are wary about the stability of equity capital and the ability to raise further equity quickly. On the first point, it is true that members of a cooperative who provide funds, which can be deemed to be equity capital can ask to be paid back by the cooperative every year. The cooperative has to make such paybacks. If a large number of members make similar demands, then the institution is threatened. This cannot occur with shares, whose transfer between shareholders does not affect the level of equity capital available. As a result, the regulator is quite tempted to view share certificates in a cooperative more as a form of debt. This is all the more the case, as they are often sold as a financial investment to clients of the cooperative bank.

Another difficulty in the event of financial distress concerns the speed with which cooperative banks can issue new share certificates. Following the implementation of the Basel regulations, all financial cooperatives have embarked on ambitious plans to issue share certificates. Without going into too much technical detail, different types of share certificates exist, some of which enhance cooperatives' stability. Efforts to collect and reinforce capital have met with some success, but for long time spans. However, this is not enough in the face of short term liquidity shortages. In this case, the essential thing is to have the capacity to react quickly when incidents threaten bank liquidity. What matters most is the possibility of accessing sources of liquidity as quickly as possible. Rightly or wrongly, it often seems that of all possibilities for obtaining liquidity, the reactivity of shareholders is greater than that of members of cooperatives.

The "Total Loss Absorbance Capacity" (TLAC) and the "Minimum Requirement for Eligible Liabilities" (MREL), as a percentage of TLAC, are new ratios that have been established to deal with liquidity issues. Leaving aside technical questions, the basis of these ratios is the "bail-in" mechanism, in other words the capacity of banks to mobilise resources to meet liabilities, aside equity capital, in order to absorb losses that threaten the survival of the institution. These mechanisms are now much under discussion, and the ability of transforming certain types of bearers of bank-issued bonds into shareholders in an authoritarian manner raises legal issues. Here again, cooperatives and their

\footnotetext{
${ }^{2}$ Supervisors introduced Total Loss Absorbance Capacity or TLAC as a new indicator of resources that can be mobilised in a balance sheet, to meet exceptional losses.
} 
system of share certificates, that can be paid out to members on demand, are especially affected. So the question of their current remuneration needs to be looked at.

\subsection{Strengthening liquidity}

Equity capital was very much an issue at the forefront in the years 2010-2015. Many banks strove to comply with the new Basel III thresholds, under pressure from the rating agencies in particular. Today's main issue concerns liquidity, and all thresholds have to meet by 2019. We have already briefly looked at the ratios to be used (LCR for 30 days and NSFR for one year). A detailed analysis of these elements takes into account the numerator and denominator of each of these ratios, ${ }^{3}$ and makes it possible to anticipate the consequences for financial institutions.

Liquidity risks lay at the heart of several bank restructuring operations in France, such as with Dexia or Crédit Immobilier de France. They were operating using a non-viable refinancing model, despite having equity capital. Northern Rock in 2007 in the UK, Washington Mutual and the Royal Bank of Scotland in 2008 were similarly affected. At some point, these banks were no longer able to access liquidity in the financial markets due to investor wariness. The drop off in liquidity put them in great difficulty in meeting their commitments and they were unable to access other sources of funding. It also became apparent that most of France's major banks were operating with insufficient liquidity, in other words, loans granted exceeded the sum of available deposits accounts. The dependency on refinancing through borrowing in capital markets is always held to be risky, and weighs on banks' ratings. Similarly, demands by clients to extend loans were not balanced by the lengthening or greater stability of deposits. Most bank deposits are sight deposits and are therefore subject to significant variations.

The awareness of the fragile financial structure of certain bank balance sheets has led to several changes, notably with the aim of consolidating and diversifying access to liquidity:

i- $\quad$ Business policy: this is surely the most visible consequence for consumers. France is one of the few countries to have allowed a situation of insufficient liquidity to arise, in other words to have a stock of bank deposits which are less than loans granted. This is even true for the cooperative banks, which historically were in the opposite situation, with far more deposits than loans. The indicator measuring this phenomenon is the employment/resources coefficient (CER). ${ }^{4}$ The ratings agencies have penalised and continue to penalise institutions with a CER $>1$, because they are dependent on financial markets for refinancing. The retail banks have taken this situation into account and have adopted, or attempted to adopt, changes in their business policy to reduce the gap between the two components of this ratio, in order to return to a more balanced position. This has led the banks to review their relations with their customers. From about 2012 onwards, account managers have been clearly instructed to achieve more balanced relationships in terms of liquidity. For years, the main priority was to sell loans, accompanied possibly with the hope of recovering flows and savings from their clients. But this latter objective was not

\footnotetext{
${ }^{3}$ BIS, Basel Committee, Basel III: The Liquidity Coverage Ratio and liquidity risk monitoring tools, January 2013. BIS, Basel Committee, Basel III: The Net Stable Funding Ratio, Consultative Document, 11 April 2014.

${ }^{4}$ Total credits granted to clients/Total deposits by clients.
} 
followed up much. This requirement has now been strengthened, although legislation does not demand this. As a result, two situations may be observed: banks do not provide all financing demanded buy the borrower or they put pressure on customer to manage more savings and current accounts from them. This reduces liquidity needs. This change in business policy has taken place quite quickly, and has been strongly felt by customers, who have not fully understood the reasons for it, and have viewed it as a worsening of their bank relationships.

In the same vein, it can be pointed out that some banks linked to car producers, such as PSA Finance or RCl Banque (Renault group), have begun collecting deposits by offering savings accounts. This acceleration in the collection of deposits risks keeping relatively high interest rates on such accounts. Special offers by some market players of interest rates at between $3 \%$ and $4 \%$ for several months bear this out. Another indicator is the interest rate on France's traditional savings account for small savers - the Livret A - which is surely overvalued at present, given prevailing economic circumstances. Changes in this business strategy have stretched interest rate margins - the main source of income - a little. This, however, complicates banks' capacity for increasing equity capital out of profits.

ii- The acquisition of retail banks in developing countries: many institutions in these countries have an excess of liquidity coming from an amount of deposits higher than credits. In these countries, the number of depositors is growing with the trend to opening accounts leading the granting of financing. Even if there is no transfer of liquidity between merged entities, consolidated accounting methods mean that all deposits and loans can be consolidated in the same balance sheet. Liquidity ratios are assessed mainly using consolidated accounts, so that the ratios may improve mechanically.

iii- Access to liquidity in the markets: In situations where there is a lack of liquidity, access to financial markets is unavoidable. Banks generally have two options. Either they can turn to the interbank market, or they can access classical market debt directly. The interbank market was relatively unreliable in providing liquidity after the collapse of Lehman Brothers and at the height of the euro crisis. Banks lost confidence in the market and the ECB had to intervene to re-establish some visibility. However, quantitative easing will not continue indefinitely. Banks have turned more and more to debt markets to refinance themselves recently. But this supposes that:

a. Markets are given visibility through the proposal of creating a multi-annual programme to provide access to liquidity, indicating when a bank issues paper and for how long.

b. Better long term and short term management of ratings in order to provide visibility of interest rates offered to investors. Tracking such ratings is particularly sensitive as the least worries linked to a downward change in ratings may provoke a liquidity crisis. In the autumn of 2012 , for example, the cut in the rating of the PSA group led to an automatic fall in the rating of PSA finance. The 
French government was obliged to intervene to guarantee access of the French car-maker's bank to markets as investors adapted to this new situation.

iv- Managing the banks' balance sheet: this last change follows modifications in regulations in terms of liquidity. It concerns the necessary adaptation of investment policies and investments. Indeed, the very definition of the LCR and even more the NSFR ratios assumes the availability of balance sheet assets with low risks when being transformed into liquidity. Accordingly, banks are tempted to hold high quality assets, above all government bonds. There is thus a danger that banks buy more of such assets, at the expense of providing credit to companies or buying up corporate bonds.

v- $\quad$ Another evolution linked to these new ratios lies in the comeback of securitisation. This technique was emblematic of the subprime crisis, the main channel through which the banking crisis was transmitted to the whole economy. Securitisation is now being used more and more by the banks. Indeed, given that the ECB recognises the quality of such security issues, banks are once again tempted to use securitisation to make their best loans more liquid (mortgage loans on housing): in other words credit with the highest ratings. This constitutes a return to the historical balance sheet management practices that were misused by American banks in the 2000s.

The question of liquidity securitisation is not therefore merely a simple technical matter. Instead, it affects the whole of an institution's strategy, as do the new equity capital requirements. These two ratios have thus become the essential determinants of top managements' strategic choices.

\section{Improving the Control of Financial Institutions}

The prudential regulations issued by the Basel committee not only concern quantitative ratios. They also have a qualitative dimension stemming from the implementation of supervisory measures. These are based on the "Supervisory Review and Evaluation Process" (SREP) which translates the philosophy of Pillar 2 of the Basel regulations. SREP deals both with the control of levels of equity capital and liquidity, the definition of an institution's "risk appetite" and the governance mechanisms set up to ensure supervision of these issues. Changes are surely likely to be most sensitive for actors concerning the question of governance, notably governance of financial cooperatives (2.1.). It should also be noted that as part of the continuity of these supervisory measures, major financial groups will have to present their organizational structures in which responsibilities for controls are clearly identified (2.2.).

\subsection{The strengthening of financial institutions' governance}

The roles of governance, top management and company boards are central to the systems of internal control set up by financial institutions (Lamarque \& Karfoul, 2009). The concern for the quality of governance however does not only affect questions of control, but also reinforces the weight and contribution of control in strategic decisions and in the fixing of risk taking. This shift is the logical consequence of criticisms made by the authorities of the passivity of governance bodies (company boards and supervisory boards) about controls over risk-taking by institutions which these bodies 
should have been supervising in theory. In July 2015, the BCBS published its latest recommendations on the principles of company governance for the banking sector.

i- $\quad$ Regulatory requirements in terms of governance quality

Since 2012, these requirements have mainly been fixed by the European Banking Authority (EBA), which was given its official mandate as part of CRD 4 (Art 91-12) to put forward Guidelines. The latter relate to the competence, experience and honorability of top executive managers: the Management Body. These guidelines are generally translated today as requiring managers and directors to be "fit and proper", and are grounded in the following principles:

a. The allocation of enough time by top managers to their commitments;

b. Adequate knowledge, competence and collective experience;

c. Concepts of honesty, integrity and independence of judgement;

d. Concepts of human and financial resources that are adequate for the training of members of the executive and the supervisory functions of the bank;

e. Concepts of diversity.

\section{EBA guidelines for "Fit and Proper" board directors}

\section{Appropriate knowledge and experience}

- Relevant training: diploma, on-the-job learning, in-house training programmes

- Relevance of the content of training: banking, finance, insurance, economics, law, management

- Specific knowledge of strategic planning, risk management, rules of governance and analysis of financial statements

- Work experience: level of responsibilities held, duration (five years), number of subordinates, size of organisation, date of leaving position (3 years at most)

2. Professional behaviour: search for indices aiming to verify such behaviour:

- Potential conflicts of interest with other functions, relations between interested parties and shareholders or companies in the group, relations with senior executives

- Excessive number of mandates/directorships (positions held)

- Verification of directors' independence in the positions given to them

3. Skills: decision-making abilities, a faculty for judgement, communication capacities, abilities to detect risks, leadership, loyalty, independence, power of persuasion, resistance to stress, capacities to work with others, courage, etc.

\section{The weighting of the above criteria according to:}

-The characteristics of the financial institution: the nature of activities, size (employees, balance sheet, number of clients)

- The functions the person will need to conduct: chair of the company board - the ability to act as chair, leadership, strategic direction

- Collective expertise by the board: checking whether the expertise of the board is guaranteed by the candidate. In case the director is replaced, checking the expertise he/she applied, in order to replace it and reinforce the training of present administrators in the area 
These principles affect not just members of bank's top management but also persons responsible for supervision, in other words banks' company boards. Specific criteria are not assessed here. However, it is to be noted that as of 2012, the EBA set out factors to help evaluate a certain number of characteristics of the individuals concerned (see Box).

The principles of bank governance put forward by the Basel Committee on Banking Supervision in July 2015 support the same approach. They include points on the composition and qualifications of company boards. There is thus a general convergence for raising the level of expertise of governance bodies so that they can increase their supervisory powers over management decisions in good conditions, and so that boards can challenge such decisions. But also, boards should undoubtedly be able to meet their responsibilities concerning strategic choices and policy risks.

These changes led moreover to stricter control by supervisors of the quality of governance and challenges to certain appointments of bank directors and top managers. The result is a form of certification of members of leading governance bodies, to check whether they can really carry out their missions. The desired profile of directors and the way they are selected have been directly affected by this new regulatory context.

\section{ii- $\quad$ Consequences for the recruitment of directors}

The very use of the word recruitment for directors may seem incongruous, given that they are elected by general assemblies of shareholders (for banks with publicly listed shares), or by certificate shareholders (or their representatives for cooperative banks). There are no plans to change the way board members are appointed. Independent directors must also be elected by general assembly. However, it is clear that candidates for election will have to meet the "fit and proper" criteria.

The task is not easy, whatever model the bank adopts. Large, publicly listed banks, with a majority of independent directors, will need to put up candidates for election who have both the necessary financial skills and also the time to carry out their missions. This is not always easy, and suggests that the number of mandates held by any one director should be limited, if banks want to see renowned directors elected to their boards. As for the small number of family banks which still exist, electing board directors with no experience to represent shareholders may raise problems when the expertise of boards is assessed. Other consequences for governance also include the obligation of separating the role of chairman of the board and CEO (chief executive director), and no longer having one person doing both jobs.

Electing directors with experience in finance is even more difficult for cooperative banks. As cooperatives of customers, these banks have governance systems that lead customers to be elected to governance bodies. In these systems, financial expertise used to be secondary in view of members' interests. The application of the principles means that certain chairpersons elected by the boards of cooperative banks have already lost their status as executive directors. Crédit Agricole even filed a suit with France's top administrative court (Conseil d'Etat) on this matter in October 2014. But it is likely to be more difficult to find candidates for directorships that have the necessary skills to meet the new principles. These banks must therefore examine new ways of retaining both the specificities of their business model and the ability of constituting boards which bring together the right skills so that they can be effective collectively. 
Furthermore, all banks are set to train their board members in order to raise their expertise. However, in view of the complexity of managing banks and its associated regulations, it is not sure that training programmes currently being designed will be enough to bridge the skills gap. Apart from this compliance which worries many actors, it is widely recognised today that the effectiveness of governance bodies and the quality of their decision-making contribute to banks' competitive advantage. Many companies have started work to increase boards' effectiveness and the quality of their contributions.

\subsection{Clearer organization and responsibilities}

Following these changes, regulation of the functioning of financial groups as a whole reflects the principles put forward by the Basel Committee. CRD 4 clearly reflects the will to see the missions and responsibilities of central bodies being defined unmistakably, especially concerning risk management. Accordingly the Directive stipulates:

i- $\quad$ In terms of supervising credit risks, it is necessary to have an overall measure for consolidated groups, a common rating and the definition of the body responsible for rating;

ii- $\quad$ The solvency and liquidity of the central body as well as all its affiliated institutions must be followed up using consolidated accounts for these institutions;

iii- The management of the central body is empowered to give instructions to the management of affiliated institutions.

For the first point in particular, the implementation of instruction memorandum BCBS 239 of January 2013 illustrates well the necessary changes in organisations and their governance. This instruction memorandum relates to the aggregation of risks in group finances as well as the reporting of risks. The memo stresses in particular the importance of reinforcing and improving "infrastructures" (in terms of information organisation and systems). The aim is to provide the best possible information in reporting to governance bodies and top management, so that they can identify, assess and manage risks. ${ }^{5}$

More generally, the reinforcement of risk management skills is expected to take place quickly, in view of improving decision-making and ensuring effective supervision of groups' entities. The aim is to have truly a better vision of exposure to risk on a consolidated basis.

From this perspective, the operation of financial groups has been questioned and institutions are in the process of changing their organisation and governance, more or less rapidly. The cooperative banks surely have to meet the greatest challenges. On the whole, they are strongly decentralized in France, and these regulatory changes oblige them to adapt the way they operate, and it has been possible to observe changes in these groups' structures.

For a while, Crédit Agricole considered a Reorganisation of its Central Body (Réorganisation de son Organe Central, or "Projet ROC" ). The project involved transferring the functions of the central body set out above from the company listed on the stock exchange (Crédit Agricole SA or CASA) to a National Federation of the Crédit Agicole (Fédération Nationale du Crédit Agricole). The latter today

\footnotetext{
${ }^{5}$ BCBS 239, Principles for effective risk data aggregation and risk reporting, January 2013. http://www.bis.org/publ/bcbs239.pdf
} 
is an organization that owns a majority of CASA shares through a holding company. Finally the project did not go ahead, but its highlights the complexity of governance structures for cooperatives and mutual in general, as well as the difficulties for the bank regulators and supervisors to decipher them. Crédit Agricole nevertheless went ahead to make adjustments to governance, by bringing political authorities onto the board of CASA. The bank has also clarified the financial structure of the group by selling the cooperative investment certificates it held in regional banks to regional bank themselves.

In the same vein, in 2013 the BPCE group simplified its capital structure when its regional banks bought back their cooperative investment certificates from Natixis, which had been supporting a certain number of subsidiaries on behalf of the group. The distribution of roles between BPCE, the central body and the listed structure of Natixis is clear and has been consolidated by the strict separation of capital ties between the regional parts of the group (Caisses d'épargne and Banques Populaires), and BPCE on the one hand, and between BCPE and Natixis on the other hand.

For its part, the National Confederation of Crédit Mutuel (Confédération nationale du Crédit Mutuel or (NCM) is the organisation which heads the banking group and is the central body of a network. The latter includes 19 federations and the Caisse central du Crédit Mutuel. In terms of regulations, the National Confederation represents the regional groups with the public authorities. It guarantees the cohesion of the group and provides services of common interest. Today the CNCM has the legal status of a non-profit organisation, but is set to become a cooperative company once present legal and conflictual issues have been resolved. For its part, the ECB has made it known that it would like the CNCM to be a public limited company.

These three examples of major French financial cooperative groups illustrate well the importance of clarifying their organisation and governance, in order to increase their efficiency but also their external transparency. The examples have followed directly changes in the Basel texts, since 2010. These texts have addressed such structural questions as much as the issues of equity capital levels and liquidity. However, it remains difficult here to describe the consequences of the relations between the regional entities and the central body. Indeed, several studies have shown that the regulatory measures are encouraging the increasing centralisation of decision-making, which in turn is undermining a key component of the differentiation across banks (Ory et al., 2006; Ory et al., 2012, Deville \& Lamarque, 2014). In fact, it is increasingly said that the cooperative model is becoming hybrid as it draws on the conventional model of banking.

The traditional banks are also being affected by these regulations. At the national level their structures are being integrated. But with a far greater international presence and subsidiaries that have been bought up, these banks must present high-quality information to supervisors. This raises numerous questions in terms of consolidation and steering, and several banks have had problems with this.

\section{Conclusion}

This chapter has sought to provide quite a general assessment of the impact of Basel regulations on solvency and liquidity ratios of retail banks, as well of associated changes in internal control and governance measures. The consequences have been numerous, and have considerably affected the 
functioning of institutions. They have led to changes which, viewed from outside, may appear to be merely technical.

However, the conditions of a profound change in banks' business model have been implemented. To begin with, conditions for financing the economy, the requirements for equity capital and liquidity are providing a new framework for the ability to lend. Moreover, the French and European authorities clearly expect bank intermediation to diminish, to the advantage of financial markets. The retail banks have therefore started analysing how to adapt to these new conditions, by having fewer branches, by becoming financial advisors rather than just being lenders, by helping companies combine various sources of financing, etc. Apart from adapting marketing practices, banks are dealing with the upheavals of a new organisational and governance model. This is especially so for cooperative banks. They are being destabilised by requirements about organisational structure, the quality of data, as well as the clear identification of individual and collective responsibilities. Banks must therefore carry out a twofold business and organisational transformation, as other major changes to their operating environment are taking place (most notably the digital revolution).

The accumulation of regulations in a very short time span may be regretted, along with instability and a clear and notorious under-evaluation of their internal human consequences for banks' employees. The tensions generated by this context risk moreover mitigating the scope of financial and technical developments that have been promoted by the Basel Committee. These tensions could lead to operational risks and the emergence of alternative actors that are free from all constraints.

\section{References}

BRI, Comité de Bâle, Bâle III : Ratio de liquidité à court terme et outils de suivi du risque de liquidité, Janvier 2013

BRI, Comité de Bâle, BCBS 239, Principles for effective risk data aggregation and risk reporting, Janvier 2013. http://www.bis.org/publ/bcbs239.pdf

BRI, Comité de Bâle, Bâle III : Ratio structurel de liquidité à long terme, Document consultatif, 11 Avril 2014

BRI, Comité de Bâle : , Juillet 2015

Deville Aude, Lamarque Eric, "Diversity of cooperative bank governance models questioning by regulation: An international qualitative research ", Working paper, Chaire Management et Gouvernance des cooperatives financière, IAE de Paris, Mai 2015.

European Banking Authorities, Guidelines, 2012.

Karfoul Hazem, Lamarque Eric "Gouvernance des banques et maîtrise des risques ", Revue Française de Gouvernance d’Entreprise, n5, Septembre 2009.

Lamarque Eric, Stratégie des banques et des assurances, Dunod, Paris, 2015.

ORY Jean-Noël, GURTNER E. et JAEGER M. (2006) "The Challenges of the Recent Changes in the French Cooperative banking Groups", Revue Internationale de I'Economie Sociale, RECMA (référencée ESSEC et ECONLIT), October - version française dans le numéro de juin 2006 
ORY J.N, De SERRES A., JAEGER M (2012), "Comment résister à l'effet de normalisation : le défi des banques coopératives", Revue des Sciences de Gestion, n²58, novembre 